\title{
Design and performance evaluation of portable folding type solar dryer for drying of amla candy
}

\author{
V.D. PARADKAR AND D.J. SHRINIVASA
}

Received : 01.08.2017; Revised : 27.08.2017; Accepted : 13.09.2017

See end of the Paper for authors' affiliation Correspondence to :

\section{V.D. PARADKAR}

College of Agricultural Engineering and Technology, Dr. Balasaheb Sawant Konkan Krishi Vidyapeeth, Dapoli, RATNAGIRI (M.S.) INDIA Email : paradkarvd@gmail. com
-ABSTRACT : The research was conducted to design and evaluate the performance of portable folding type solar dryer for drying of amla candy. The developed dryer consist of chimney, chimney stand, drying chamber, polyethylene sheet with mosquito net as dome and perforated try. The dryer had capacity of $2 \mathrm{~kg}$ per batch of amla candy of thickness 6 to $7 \mathrm{~mm}$. The dimensions of dryer were $0.9 \mathrm{~m}$ length, $0.6 \mathrm{~m}$ width and $0.6 \mathrm{~m}$ height. The collector area was $0.539 \mathrm{~m}^{2}$ with drying cabinet size of $0.9 \times 0.6 \mathrm{~m}$. The total cost of construction of dryer was Rs. 1349. Wet amla pieces with and without sugar were selected as drying material. The dryer was tested for its performance at without load and with load. During no load test maximum temperature achieved in dryer was $61.6{ }^{\circ} \mathrm{C}$. The moisture content of $6 \mathrm{~mm}$ thick amla pieces treated with sugar was reduced from $281.67 \%$ (db) to $29.93 \%(\mathrm{db})$ in 600 minutes. While moisture content of amla pieces without sugar was reduced from $718.33 \%(\mathrm{db})$ to $58.56 \%(\mathrm{db})$ in 600 minutes. The drying rate of amla pieces with sugar and without sugar had peak value of 1.4126 and $1.6777 \mathrm{~g}$ water per gram dry matter per hour, respectively during drying time interval of 8.30 am to 9.30 am of the day. The temperature reached in the dryer was 15 to $20^{\circ} \mathrm{C}$ higher than atmospheric temperature.

- KEY WORDS : Amla, Amla candy, Foldable, Portable, Solar dryer

-HOW TO CITE THIS PAPER : Paradkar, V.D. and Shrinivasa, D.J. (2017). Design and performance evaluation of portable folding type solar dryer for drying of amla candy. Internat. J. Agric. Engg., 10(2) : 537-544, DOI: 10.15740/HAS/IJAE/10.2/537-544. 